\title{
Question-Answer in 'Ayat-Ayat Cinta' (A Study of Speech Act in Novel)
}

\section{Batmang Batmang}

Institut Agama Islam Negeri Kendari, Indonesia. E-mail: batmang_75@yahoo.com

\begin{tabular}{l} 
ARTICLE INFO \\
\hline Keywords: \\
Ayat-ayat Cinta; speech \\
acts; question-answer. \\
\\
How to cite: \\
Batmang, B., 2018). \\
Question-Answer in \\
'Ayat-Ayat Cinta': (A \\
Study of Speech Act in \\
Novel), 4(2), 84-90. \\
DoI: \\
http://dx.doi.org/10.31332/ \\
lkw.v4i2.984
\end{tabular}

\begin{abstract}
This study aims to obtain information related to the forms and the uses of linkages adjacency pair of 'question-answer' used in AyatAyat Cinta, as well as understand the function of the adjacent pair in establishing the integrity of the novel discourse. This study is a qualitative study which is operationally using the principles of speech act study. The speech act referred to in this study is a dialogue in the novel which becomes the data source of this research. The following procedure collected data: (1) to identify the overall dialogue in the novel; Ayat-Ayat Cinta; (2) to determine the adjacent pair in the form of "questions-answers."; (3) to find the forms and the links between each pair of utterances focused on "question-answer" type. The research findings indicate that the adjacent pairs of "questionanswer" are found in the following forms: (1) short sentences; (2) ellipsis (3) deep structure; and (4) informal language (slang). The function of the adjacency pairs of "question-answer" in this novel is as controlling the integrity of discourse, namely (1) to express pleasure/choice of the characters; (2) to explain the identity, background and character of the characters; and (3) to reveal the history of the past of the characters.
\end{abstract}

\section{Introduction}

In a conversation that occurs between two or more people, the speech of a speaker requires a response from others to be involved in communicative interaction. In the study of speech acts, this is referred to as adjacency pairs. The concept of the adjacency pairs was originally developed by Shegloff \& Sacks. Adjacency pair is a sequence of two utterances in which speech the one following the other, or 'close to each other,' and has two parts: the first pair and the second pair part (Schiffrin, 1994). The first type used by the speaker will determine the range of responses that can be provided by other participants in the conversation because the second utterance is associated with the first utterance. In this case, a question requires an answer, the offer requires the acceptance/rejection, demands require a response, praise requires the acceptance/rejection, and the request requires approval.

Adjacency pairs are a part of characteristics of discourse. Renkema classifies discourse into two types. First, a simple monologue discourse can be seen as a discourse with sentences derived from one party, either the speaker (the oral discourse) or the author (in written discourse) and it does not require a verbal 
response from the other party. Second, the discourse of dialogue is seen as a discourse with sentences derived from the two sides' (or more) talk (dialogue); in this case there is a verbal response from the other party, and the special feature contained in the dialog of the discourse is the sentences are closely related to each other (Renkema, 2004).

The dialogue in the short story or novel is one kind of spoken discourse recorded in writing. The dialog in the literature is the direct speech of the actors of the story forming the pairs of speech. In the direct utterances, sometimes mistakes could occur because they almost ignore the grammatical accuracy. To recognize that the sentence is a direct speech, it is written between two quotation marks, and every utterance is written in the new paragraph as well as the response.

A novel of Ayat-Ayat Cinta chosen as a favorite novel of 2005 and a winner of the Pena Award of 2005 cannot be separated from the use of adjacency pairs in its script. Based on the observation, adjacency pairs that are dominant in this novel are "question-answer" type which plays very important function to the unity of the discourse in this novel. To be able to describe the form of "question-answer" and its function on this novel, research needs to be done. Accordingly, this kind of research is conducted.

Based on the background, the research problems are: 1) How is the adjacent pair of question-answer type in Ayat-Ayat Cinta?; and 2) What is the function of the adjacent pair of question-answer type in Ayat-Ayat Cinta?

Based on the research problem, this study aims to describe the form and the use of adjacency pair of "question-answer" in Ayat-ayat Cinta and to find out the relationship between question and answer pair and its function in the novel.

Some benefits that can be obtained from this study are as follows: (1) academic benefits: as an additional knowledge in linguistics study, especially in the field of speech acts; (2) the practical benefits: as an information and knowledge about adjacency pairs in particular "question-answer" type in Ayat-Ayat Cinta, which is considered as the best-selling novel of soul builders.

\subsection{Literature Review}

a. Understanding the Speech Acts

Speech act is the speech as a functional unit in communication (Tsui, 1989). Speech act theory was first put forward by the two philosophers; John Austin and John Searle. Both experts stated that the language used not only to describe the world but also to undertake actions that can be traced from the speech itself (Werth, 1991). Furthermore, Werth writes that the approach of speech acts in discourse focuses on the knowledge of the underlying condition to generate and interpret the actions through words (Werth, 1991).

This term means the act of uttering speech act or tells a sentence (Gunter, 2005), The position of the pragmatics of speech act is central because, according to Jerimes speech act is the basis for pragmatic analytical topics such as presuppositions, implicatures, conversations, etc. If a speaker says something, it means he also acts. It includes activities uttering a sentence with a specific purpose called speech act according to Jerimes (Jerimes, 1994). 


\section{b. Monologue and Dialogue Discourse}

The monologue is single talk without others talking. Monologue discourse does not need other people's responses, both verbal and nonverbal. Monologue can be descriptive, narrative discourse, or argumentative (Gunter, 2005), Here is an example of the quoted monologue discourse of a comic "Pentungan" (4/9 / 2006 / XIII).

1) "Look! Even Mamat, Nino, and Deni can have many girlfriends although they are unemployment, but why am I like this?

2) I think she is also interested in me."

3) "He has to be my boyfriend? Oh, could it be ...?"

4) "How can I get acquainted with him ... should I say hello first, but I am embarrassed ...?"

The fourth example of this monologue is a sentence described through the inner mind of a speaker. In the picture the utterances are written with bubbles indicated that the speaker is a thing.

Dialogue is not the same as monologue discourse (such as news or essay). Dialog discourse tends to use numerous ellipsis, either on a line or on both lines in the dialogue pairs (Keifer, 2003). Nonetheless, there are sentences that have continuity. It is natural that the continuity exists in a different monologue with the nature of the existing dialogue (Rankema, 2004). In the monologue, the speaker or writer does not need to pay attention to verbal responses expressed by the reader or interlocutor. Therefore, the continuation of the sentences to express a proposition is determined by the speaker or writer unilaterally. As with the dialogue; a speaker must draw attention to the interlocutor's verbal response to form adjacent pairs for the dialogue (Clark, ed., 1997).

c. Definition of Adjacency Pairs

Adjacency pair is a shift change in a conversation consisting of two words by two speakers, one after the others spoke. Some experts define this term.

1) Adjacency pair refers to the 'conventional sequence' in which the utterance of a speaker depends on the remarks made by other speakers (Keifer, 2003).

2) Adjacency pair is a unit consisting of shift change from two speakers. The shift is functionally related to the other in a style such that the first turn requires the second turn.

3) Adjacency pair is a sequence of two adjacent speeches produced by two speakers, sequentially as the first part and the second part, so that they both need each other (Schiffrin, 1994).

4) Adjacency pair is the discourse of dialogue contains the sentences in pairs from two sides (or more) talk (dialogue), namely the existence of a sentence close to each other in pairs (Clark, ed., 1997),

Based on these definitions it can be concluded that adjacency pair is a sequence of two conversations: 1) Adjacent; 2) Produced by two speakers; 3) Structured as the first part and the second part; 4) The first part requires the second part. 


\section{d. Types of Adjacency Pairs}

Adjacency pair consists of two speakers' utterances that occur alternately. The utterance of the first speaker (part of the first pair) requires a speech response (the second pair, or the second turn). Experts, Clark \& Clark, 1977; Tsui Schegloff \& Sacks in 1989) classify adjacency pair into six types, namely: (1) the question-answer; (2) the offer-acceptance/rejection; (3) demand-response; (4) greetings; (5) praise-acceptance; and (6) demand-approval (Tsui, 1989).

\section{Method}

This study is a qualitative study which is operationally using the principles of the study of speech acts. Speech act is referred to in the dialogue of the novel as the source of research data.

The data source of this research is the dialogue in Ayat-Ayat Cinta by Habiburrahman El Shirazy (24th edition in 2008), with the corpus of data that focuses mainly on the adjacent pair in the form of "questions-answers."

Researchers serve as the main instrument in this research to obtain the data the aids are needed to support and assist the researcher to identify the dialog containing "question-answer." The aids are reading logs.

The data in this study were collected by the following procedure.

1. Identify the overall dialogue in the novel Love Verses.

2. Determining the adjacent pair (adjacency pairs) in the form of "questionsanswers."

3. Finding form and the links between each pair of speech "question-answer.

\section{Findings and Discussion}

a. Forms of adjacency pairs "question-answer."

"Question-answer" is the most dominant adjacency pair in Ayat-Ayat Cinta novel. The pairs consist of 97 pairs, or about $50 \%$ of all types of adjacency pairs exist. The rest is greetings (12\%); offer-acceptance/rejection (18\%); demand-response (14\%); praise-acceptance / rejection (3\%); and "demand-approval (13\%). Questionanswer is expressed in a sentence with the following characteristics.

\section{Short Sentence}

The question-answer types in this novel tend to be short and brief, for example:

\section{[1]}

Fahri : "Is it safe?"

Aisha : "safe"

[2].

Fahri : "Perform Tayammum?"

Abdul Rauf: "yes"

Sentence Ellipsis 
The question-answer types in this research largely are ellipsis form. The first pair shows the ellipsis in the questions and answers; the second pair only applies to the question, and the third pair also applies to the question. Each ellipsis can be described using "counter-ellipsis" test.

[3]. A-Maria : "When you're home?
AA-
Maria : "When are you coming home?" (Cons ellipsis)
B-Fahri : " at 5, Insha Allah"
BB-Fahri : "I will be home at five, Insha Allah." (Cons ellipsis)

The "are you" part on [3] AA and "I will be home on [3] B is omitted in each line of the dialogue.

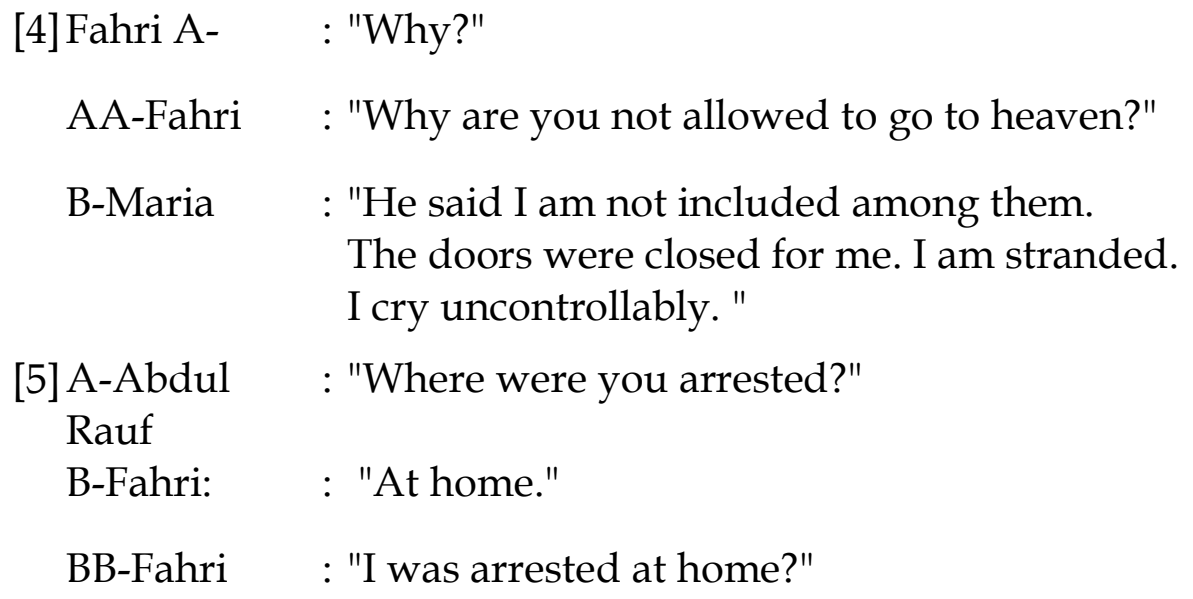

The element you are not allowed to enter heaven in [4].AA and I was arrested in [5] BB is omitted to be ellipsis type. By undertaking counter-ellipsis test, it is easier to explain the ellipsis process in these examples. It is clear that there is a relationship between pairs and one another which also means that there are linkages among the elements of discourse.

The deep structure

In this novel, this question is not always paired with an answer. Sometimes, the speaker responds certain question by using another question.

[6] Magdi : "Is there something wrong "Fahri?

Fahri : : "Where is Saiful?"

[7] Police : "You are Fahri Abdullah?"

Fahri : "What's wrong?" 
The responses in the form of questions are also included as adjacency pairs because of the deep structure. The question appearing as a respond for certain question implies doubts about a situation/ specific situation.

\section{Informal language Variation}

Some dialogues in this novel also use informal language or slang which is often used as a daily language by the author. The underlined words are some slang words in Indonesia.

[8]. Fahri: "Di Jerman kalau berangkat kuliah gimana?"

How do you go to campus?

"sering berdesakkan seperti tadi nggakk?"

Is it always in a rush like this?

Aisha: "Transport in Germany is unlike in Egypt.

And incidentally, I rarely take public transportation."

b. The function of "question-answer."

1) To explain the identity, background, and characters, for example in the following dialog.

[10]. Fahri: "How can Nurul be in this bad condition Ustadz?

What happened to her, and what can I do to help? "

Ustaz "You know Nurul is the only child of Mr. KH Jafar

Jalal: Abdul Razaq, the Islamic boarding school in East Java. She is not only beautiful but also kind-hearted. Since she was in the first year, many Islamic scholars propose Nurul for their sons. Nurul does not want to. When she eventually studied at AlAzhar, the marriage proposal is coming even more. Nurul's father repeatedly called her to immediately determine the choice of her life companion. He felt terrible about continuously rejecting the proposal. What more if the proposal was coming from scholars who are more senior than him."

2) Answer questions as a way to reveal pleasure or character selection, as shown in the following dialog.

[9] Fahri : "Where are my nieces, Ustaz?

Why did not you bring them along?

Ustaz : "Once in a while, we like to travel unhindered both

Jalal children. Let a little tenderness. This morning we enjoyed the trip to the metro. From Ramsis to Hadayek Helwan, it was calm, and the weather was cool, " 
3) To unveil plans for the future and the history of the characters, for example in the following passage.

[11] Fahri:

"What do you mean Aisha?"

Aisha

"Here, God willing, you will write your thesis, translate and produce great works that are beneficial for the people. And I'll be your best companion day and night. Oh, My husband, the flat was bought by my mother three years before she died when she was asked to teach at the Faculty of Medicine of Univesity Cairo for three semesters. For six months we stayed in this house. This library was my bedroom at that time. After we got back to Germany, it was rented to the embassy staff. The last tenant was Edward Minich, Trade Attache. This apartment was inhabited by important people. Right below us is an official Argentine embassy on top of our leading Egyptian director. In addition to us, flat number 20, the owner of Wadi Nile Travel. "

\section{Conclusion}

The adjacency pair of "question-answer" in Ayat-Ayat Cinta is mostly in the form of short sentences. Dialogues are also made in the form of an ellipsis sentence which means that some of the sentence parts are omitted. The response to questions in the dialogue sometimes is in the form of questions as well based on its deep motivation structure. Some dialogues also use informal language or slang language.

Question-answer in this novel serves as a controller of the integrity of the discourse. The responses of the question make the authors be able to (1) express pleasure/selection of the characters; (2) explain the identity, background, and character of the characters; and (3) reveal the history of the past of the characters.

\section{References}

Clark, H., H dan Clark, E. (1997). Psychology and Language: An Introduction to Psycholinguistics. New York: Harcourt Brace Jovanovich, Inc.

Schiffrin, D. (1994). Approaches to Discourse. Massachusetts: Blackwell Publishers.

Chafe, W., L. (1970). Meaning and Structure of Language. Chicago: The University of Chicago Press.

Gunter, R. (2005). The sentence in Dialog. Columbia: Hornbeams Press.

Jerimes, H. (1994). Pragmatics. Cambridge: Cambridge University Press

Keifer, F. (2003). Questions and Answers. Dordrecht: D. Reidel Publishing Company.

Renkema, J.P. (2004). Conversational Style. Norwood, NJ: Ablex Press.

Tsui, A. (1989). Beyond the adjacency pairs. Language in Society, 18 (4): I 545-564

Werth, P. (1991). The Concept of Relevance in Conversational Analysis. Paul Wetch (ed.) Conversation and Discourse. London: Croom Helm. 